\title{
Implementing JIGSAW pedagogy to Enhance Learning in RES Course
}

\author{
Santosh Madeva Naik ${ }^{1}$, Hema Mahajan ${ }^{2}$, Sreeramulu M³ ${ }^{3}$ Ch Kannaiah ${ }^{4}$ \\ ${ }^{1}$ Assistant Professor Mechanical, Hyderabad Institute of Technology and Management, Hyderabad, Telangana, India. \\ ${ }^{2}$ Assistant Professor CSE, Hyderabad Institute of Technology and Management, Hyderabad, Telangana, India. \\ ${ }^{3}$ Professor Mechanical, Hyderabad Institute of Technology and Management, Hyderabad, Telangana, India. \\ ${ }^{4}$ Assistant Professor CSE, Hyderabad Institute of Technology and Management, Hyderabad, Telangana, India. \\ santoshn.mech@hitam.org \\ hemamahajan.cse@hitam.org \\ kannaiah.cse@hitam.org \\ sreeramulum.mech@hitam.org
}

\begin{abstract}
:
The traditional way is no more effective way to enhance students learning and knowledge. However, students need different methods to learn the concept practically. Renewable energy is one subject from the mechanical stream where students are required active learning techniques to boost up their confidence towards the subject's knowledge. Moreover, making students attentive during the class is a tough task and therefore implementing different pedagogy is needed to improve their understanding of the taught concept. This paper has explained the implementation of Jigsaw activity in the class and its impact on students learning.
\end{abstract}

Keywords: JIGSAW, Team work, Poster presentation, Canvas, Edmodo

\section{Introduction}

JIGSAW methodology is a student-centered activity where students are actively learning the concepts. Nur Hafizah Azmin1 [1] 2015, stated that the JIGASW methodology successfully implemented. The author explained about action research process about the implementation of the activity.

Tran Van Dat [2] 2015, in this study paper suggesting jigsaw - based cooperative learning about assessment and time. Alejandro Garcia et.al [3] 2017, stated that jigsaw is an effective learning strategy where students learn the topic collaborative way. While conducting the activity roles will be assigned to students. The instructor also should observe students are following the roles and time strictly. Micheal M. van Wyk [4] 2016, in this research paper, explained about the instructor before conducting the activity conducted pre-test and after conducting the activity conducted pro test. In the pro test students got good marks while compared to pre-test. Abdullah Aydin et.al [5] 2017, in this paper, discussed the effect of jigsaw pedagogy in a physics laboratory. Comparing the study between jigsaw cooperative learning and traditional method. Students have actively involved lab experiments in an expert group after completing the experiments students will return to home group. This pedagogy is given good results students know about all experiments procedure. Prof Anastasia Marie Rynearson and Prof Alison K. Polasik [6] 2019, described the forming of students group for activity and creation of rubrics for a jigsaw activity. The author explained the collaboration between think pair share and jigsaw activity in the lab course. Prof Jamie Gomez R et.al [7] 2017 explained by peer learning in jigsaw students will learn the concept clearly. This activity applied to chemical engineering students $(\mathrm{N}=61)$ and a smaller group of the team done with 3 to 5 students. Prof Sanjay Jayaram [8] 2013, explained about the collaboration of jigsaw activity with problem-based learning. Students are divided as home and expert group and this group will identify the problem and work on the project. The final poster will be done by the home group.

By following Alejandro Garcia et.al [3] 2017, while conducting this activity should attire to the time. This pedagogy I used because to revised the whole unit and to gain more knowledge on the topic. At first, students are divided into group home groups and expert groups.

\section{Method}

After completion of the unit, Jigsaw activity was conducted for the students. The lesson plan for the subject was shared with the students. In the lesson plan itself, pedagogy plan, outcome, and assessment were mentioned in the advance. During the activity, students are formed into team wisely and numbers will be given 1, 2, 3,4,5,6 it depends on class strength. This $1 \ldots 6$ number is called a home group this number will be repeated 1...6. After forming team 1 number will be separated from the team the same for other numbers also ( 2 no separated). The $1,1,1,1,1,1$ or 2,2,2,2,2,2 is called as expert group. Now, the topic will be given to the expert group and they have to make posters shown in figure 3 . After making posters this expert group student will move to home groups. Now, this home group 
will give the presentation on a poster that already 1 number knows about the topic. After getting into home group 1 number will explain the poster which he has already done and these home groups will give a presentation on the topic with a poster shown in figure 4 .

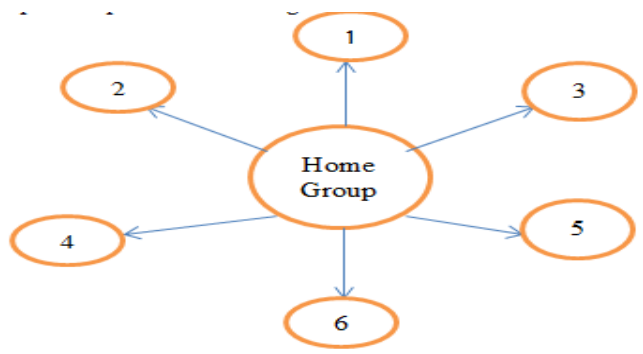

Fig.1 Graphical representation of home group

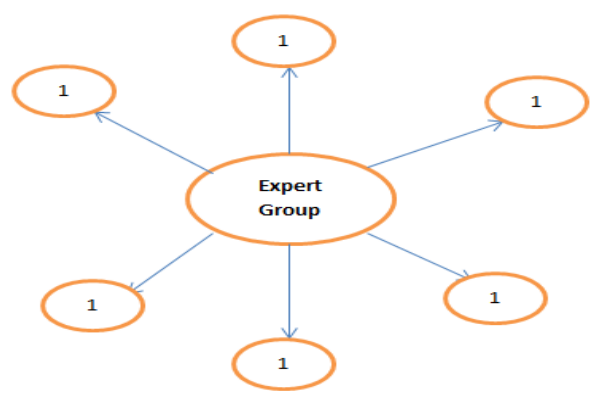

Fig.2 Graphical representation of expert group

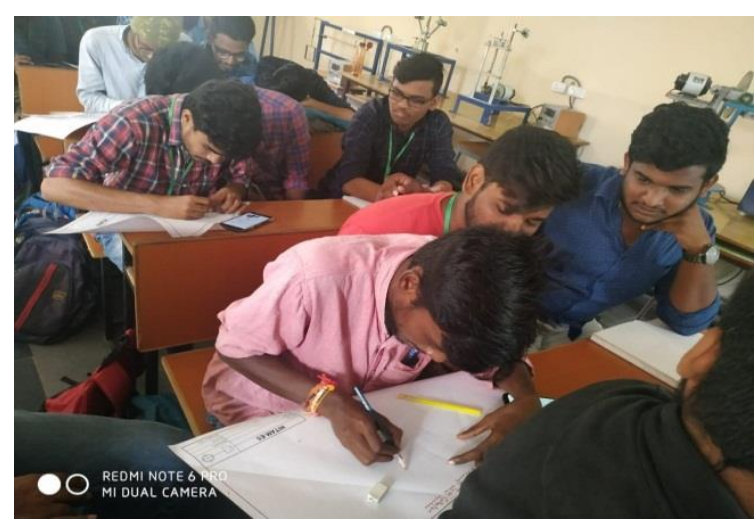

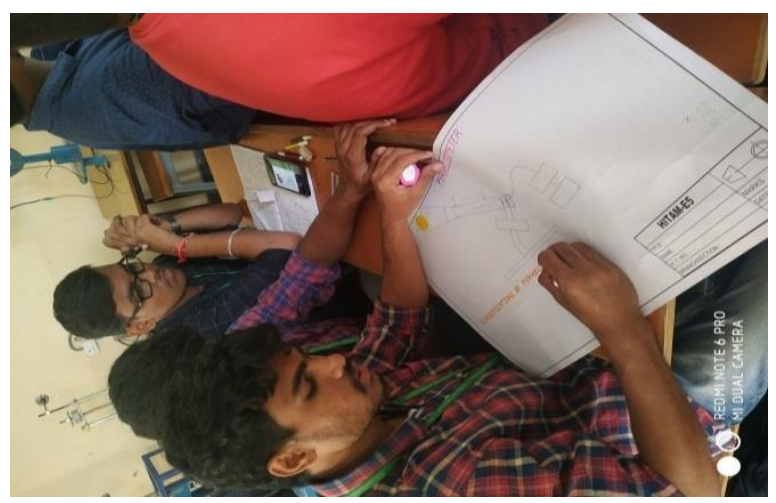

Fig.3. Expert group
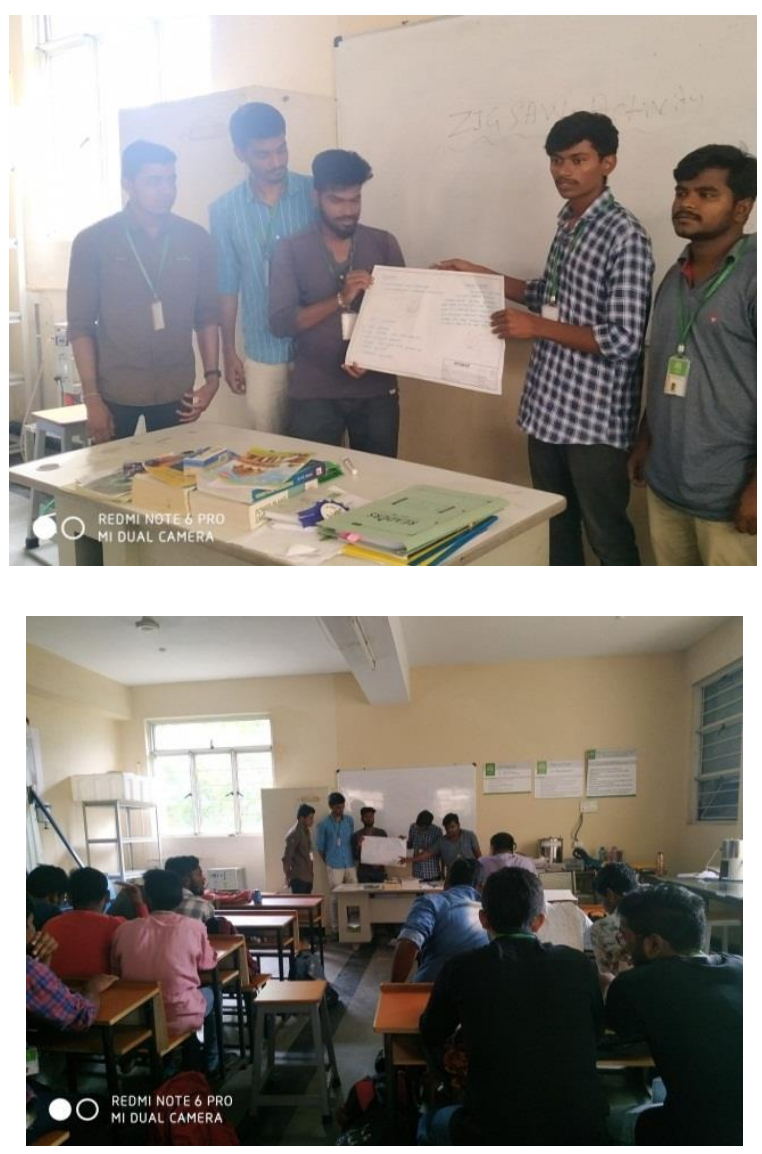

Fig.4. Home group presentation 

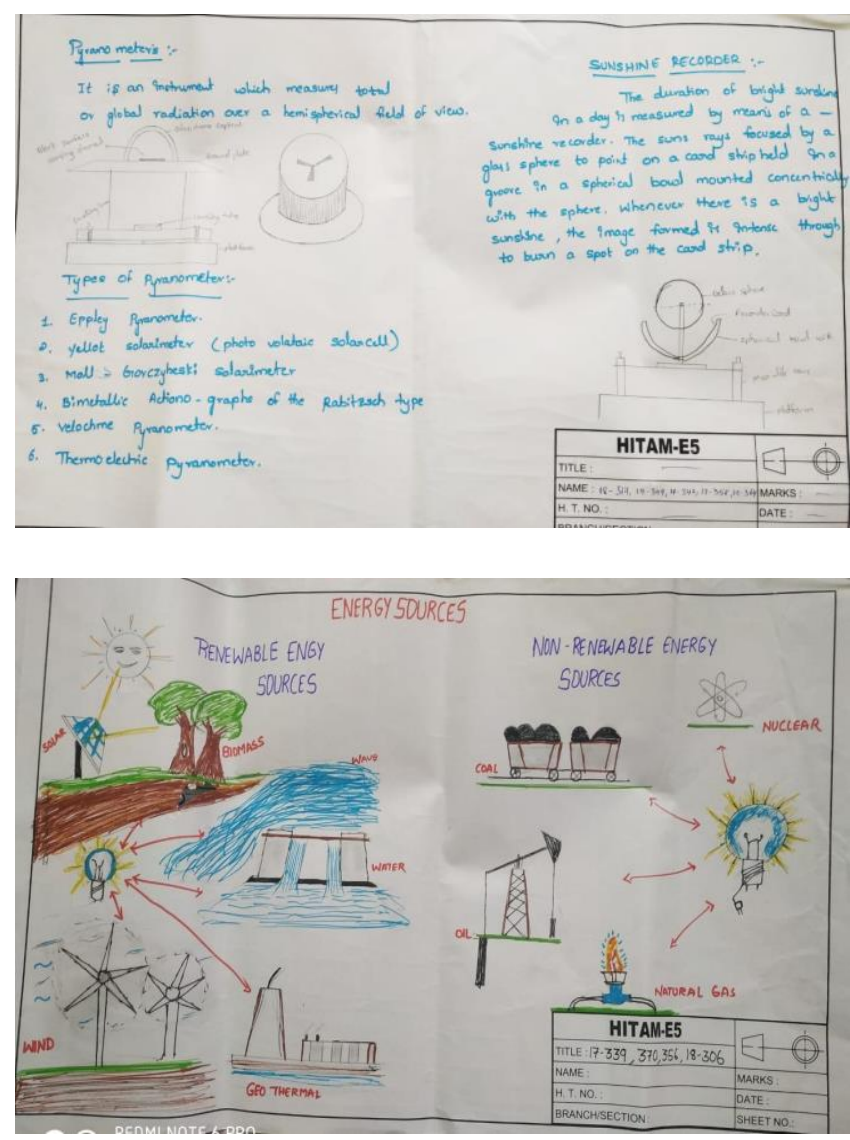

Fig.5. Poster

This activity helps the students to understand the whole unit's topic clearly. This activity has improved communication, presentation skills, and knowledge of course. Before conducting the activity Rubrics are shared with the students. After conducting the activity, feedback is taken from the students through the online goggle form. What are the topics students are understood clearly and the topic didn't understand as shown in figure 6.

Table 1. Rubrics

\begin{tabular}{|c|c|c|c|c|}
\hline \multicolumn{5}{|c|}{ Rubrics for JIGSAW Pedagogy - RES Course } \\
\hline Criteria & & Ratings & & Poin \\
\hline $\begin{array}{l}\text { Team } \\
\text { work }\end{array}$ & $\begin{array}{l}3.0 \text { to }> \\
2.0 \\
\text { The team } \\
\text { formation } \\
\text { done and } \\
\text { topics } \\
\text { clear and } \\
\text { equally } \\
\text { distributin } \\
\text { g the } \\
\text { formal } \\
\text { roles, }\end{array}$ & $\begin{array}{l}2.0 \text { to }>1.0 \\
\text { The team } \\
\text { formation } \\
\text { done and } \\
\text { equally } \\
\text { distributing } \\
\text { the informal } \\
\text { roles load. }\end{array}$ & $\begin{array}{l}1.0 \text { to }>0 \\
\text { The team } \\
\text { formation } \\
\text { done and } \\
\text { does not } \\
\text { distributes } \\
\text { the roles, } \\
\text { load. }\end{array}$ & 3 \\
\hline
\end{tabular}

\begin{tabular}{|c|c|c|c|c|}
\hline & load. & & & \\
\hline $\begin{array}{l}\text { presentati } \\
\text { on }\end{array}$ & $\begin{array}{l}3.0 \text { to }> \\
2.0 \\
\text { Presentati } \\
\text { on is neat, } \\
\text { clean, } \\
\text { well- } \\
\text { organized } \\
\text { and } \\
\text { presented } \\
\text { in a } \\
\text { creative } \\
\text { way. } \\
\text { Presentati } \\
\text { on is } \\
\text { colourful } \\
\text { and } \\
\text { creative. } \\
\text { Informati } \\
\text { on is } \\
\text { interestin } \\
g \quad \text { and } \\
\text { accurate. }\end{array}$ & $\begin{array}{l}2.0 \text { to }>1.0 \\
\text { Presentation } \\
\text { flows well. } \\
\text { Some tools } \\
\text { are used to } \\
\text { show } \\
\text { acceptable } \\
\text { understandi } \\
\text { ng. } \\
\text { Each } \\
\text { member's } \\
\text { information } \\
\text { is } \\
\text { represented } \\
\text { and } \\
\text { identified } \\
\text { with their } \\
\text { name. }\end{array}$ & $\begin{array}{l}1.0 \text { to }>0 \\
\text { Presentatio } \\
\mathrm{n} \text { has no } \\
\text { flow. } \\
\text { Insufficien } \\
\mathrm{t} \\
\text { informatio } \\
\mathrm{n} \text { and } \\
\text { lacking } \\
\text { some of } \\
\text { the } \\
\text { member's } \\
\text { informatio } \\
\mathrm{n} \text {. }\end{array}$ & 3 \\
\hline Content & $\begin{array}{l}3.0 \text { to }> \\
2.0 \\
\text { Content is } \\
\text { accurate } \\
\text { and all } \\
\text { required } \\
\text { informati } \\
\text { on is } \\
\text { presented } \\
\text { in a } \\
\text { logical } \\
\text { order. }\end{array}$ & $\begin{array}{l}2.0 \text { to }>1.0 \\
\text { Content is } \\
\text { accurate but } \\
\text { some } \\
\text { required } \\
\text { information } \\
\text { is missing } \\
\text { and/or not } \\
\text { presented in } \\
\text { a logical } \\
\text { order, } \\
\text { making it } \\
\text { difficult to } \\
\text { follow }\end{array}$ & $\begin{array}{l}1.0 \text { to }>0 \\
\text { Content is } \\
\text { inaccurate. } \\
\text { Informatio } \\
\mathrm{n} \text { is } \\
\text { incomplete } \\
\text { inaccurate, } \\
\text { or not } \\
\text { presented } \\
\text { in a logical } \\
\text { order, } \\
\text { making it } \\
\text { difficult to } \\
\text { follow. }\end{array}$ & 3 \\
\hline Quality & $\begin{array}{l}1.0 \\
\text { Excellent }\end{array}$ & $\begin{array}{l}0.75 \\
\text { Good }\end{array}$ & $\begin{array}{l}0.5 \\
\text { Needs } \\
\text { improvem } \\
\text { ent }\end{array}$ & 1 \\
\hline
\end{tabular}




\section{QUESTIONS RESPONSES 32}

\section{RES 1 - Feed back}

Before you leave class today, answer the following questions.

Name *

Short answer text

Roll No *

Long answer text

What was the most important points you learned during the activity?

Long answer tex:

Which part of the concept discussed was unclear? *

Long answer text

Learning *

Lona answer text

QUESTIONS RESPONSES 32

32 responses

\begin{tabular}{|l|l|}
\hline SUMMARY INDIVIDUAL \\
\hline
\end{tabular}

Name

32 responses

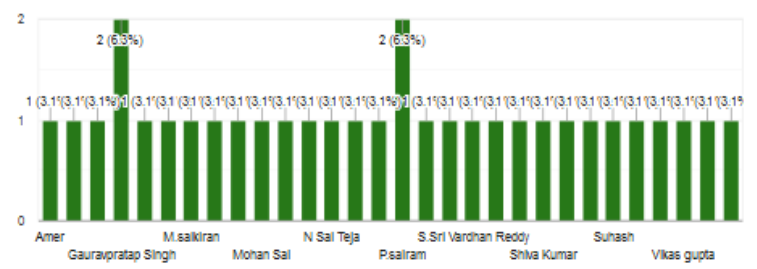

Roll No

32 responses

17E51A0363

\section{Results}

JIGSAW pedagogy is successfully implemented in the renewable energy resource course. The class strength is 44 and 32 students were given responses about the pedagogy shown in figure 6. To know topic level outcomes quizzes are created in canvas. All students were taken the quizzes on canvas. This quiz is done to assess the students how much they understand the topic shown in figure 7. For assessment, I used the canvas tool and Edmodo shown in figure 8 and figure 9 .

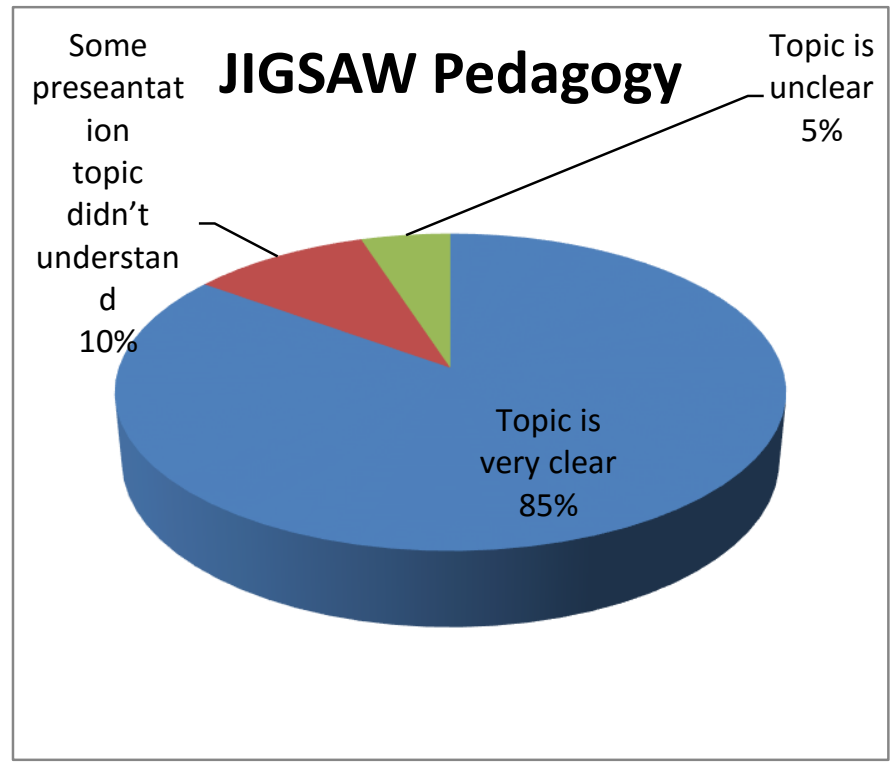

Fig. 7 Impact of the pedagogy in the class

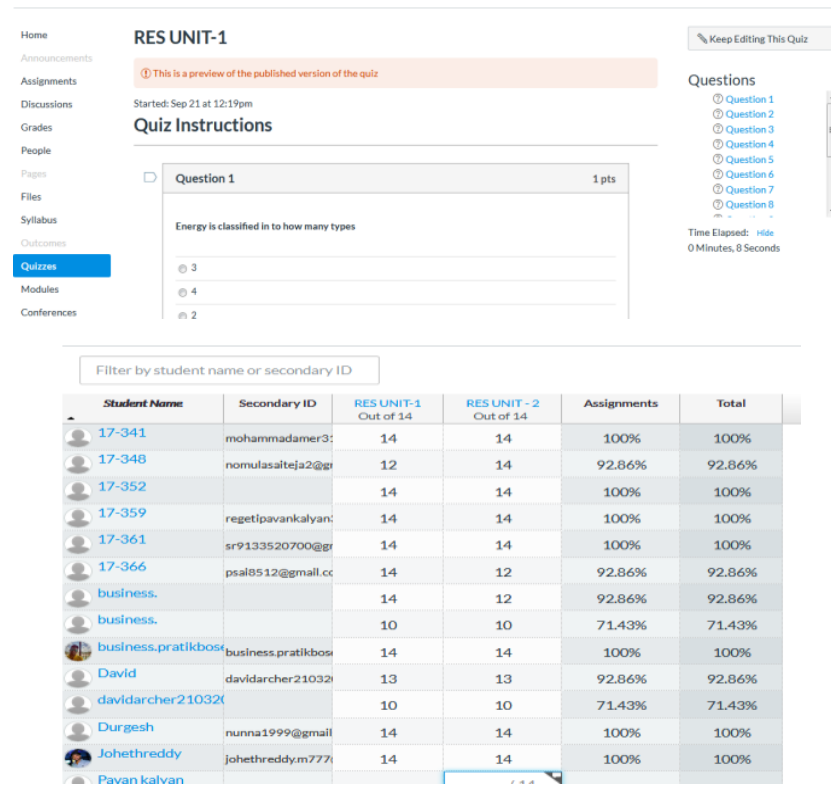

Fig.8 Assessment in canvas

Fig.6. Feedback 


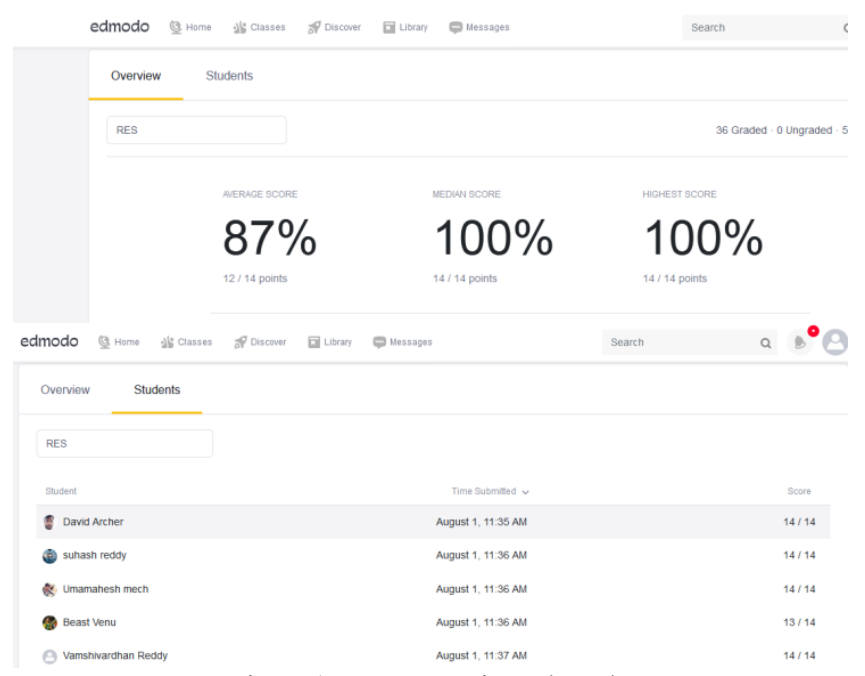

Fig.9 Assessment in Edmodo

- Students should apply their pedagogical activity knowledge to solve practical problems.

- Students will be able to learn about technology tools to update their knowledge

- Students will be working in a team and communication will be improved.

Expected outcomes at the end of the course as follows:

- Students can understand renewable energy sources and non-renewable energy

- Teamwork

- Communication skills

- Technical skills of relevant streams

- Leadership skills

\section{Discussion}

Different pedagogy is needed to make the class more active and interactive. Before conducting any activity, a proper plan, assessment, and expected outcome should be prepared. While delivering the content we have to be very confident about what we are explaining. This can be implemented in a course that may enhance the teaching-learning process; Students will get a better understanding of the concept.

\section{Conclusion}

This paper is focused mainly on the JIGSAW pedagogy, implementation process, impact on students and assessment $85 \%$ of students are given feedback that they understood the topic clearly. Feedback has conducted to know the student's learning. Quiz has conducted for the assessment. In this assessment students got marks. All students are involved in teamwork and each and every student learned the topic by making posters and presentations in the expert group and home group.

Challenges: Time management was the tough task to maintain for the instructor because some groups were completing tasks early some not. Therefore time planning would have been more effective in order to make everyone participate in the activity.

\section{References}

1. Nur Hafizah Azmi, Effect of the Jigsaw-Based Cooperative Learning Method on Student Performance in the General Certificate of Education Advanced-Level Psychology: An Exploratory Brunei Case Study, International Education Studies; Vol. 9, No. 1; 2016 ISSN 1913-9020 E-ISSN 1913-9039.

2. Tran Van Dat, Effect of the Jigsaw-Based Cooperative Learning Method on Student Performance in the General Certificate of Education Advanced-Level Psychology: An Exploratory Brunei Case Study, International Education Studies; Vol. 9, No. 1; 2016 ISSN 1913-9020 E-ISSN 1913-9039.

3. Alejandro Garcia, Jesus Abrego, Reguenes Robert, Using the Jigsaw Method for Meaningful Learning to Enhance Learning and Rentention in an Educational Leadership Graduate School Course, Global Journal of HUMANSOCIAL SCIENCE: G Linguistics \& Education Volume 17 Issue 5 Version 1.0 Year 2017 Online ISSN: 2249-460x \& Print ISSN: 0975-587X.

4. Micheal M. van Wyk, Jigsaw Pedagogy in Enhancing Economics Teachers' Learning in Free State Secondary Schools, Kamla-Raj 2016 Int J Edu Sci, 13(3): 349355 (2016).

5. Abdullah Aydin, Filliz Biyikli, the effect of JIGSAW technique on student's laboratory material recognition and usage skills in general physics laboratory -I course, Universal Journal of Educational Research 5(7): 10731082, 2017.

6. Anastasia Marie Rynearson, Alison K. Polasik, interactive and collaborative materials science and processing course with integrated lab, American Society for Engineering Education, paper id 27790, 2019.

7. Jamie Gomez R, Vanessa Svihla, Abhhaya K Datye, Jigsaws \& Parleys: Strategies for engaging sophomore level students as a learning community, American Society for Engineering Education, 2017 paper id 18351. 8. Sanjay Jayaram, Implementation of Active Cooperative learning and problem based learning in an undergraduate control system course , $120^{\text {th }}$ ASEE Annual Conference \& Exposition, June 23-26, 2013 paper id 6498.

9. Olukemi Akintewe, Jonathan Elliot Gaines, Schinnel Kylan Small, Flip j instructional strategies in the first year engineering design classroom, FYEE Conference : Penn State University, Pennsylvania Jul 28 2019, paper id 28049. 10. AliceY.Scales, Terri E.Varnado, Active learning for engineering technical graphics online environments, American Society for Engineering Education, 2012. 